medRxiv preprint doi: https://doi.org/10.1101/2021.06.11.21258730; this version posted June 16, 2021. The copyright holder for this preprint (which was not certified by peer review) is the author/funder, who has granted medRxiv a license to display the preprint in perpetuity.

It is made available under a CC-BY 4.0 International license.

\title{
Relative perceived importance of different settings for SARS-CoV2 acquisition in England and Wales: Analysis of the Virus Watch Community Cohort
}

Sarah Beale1,2, Thomas Byrne1, Ellen Fragaszy1,3, Jana Kovar2, Vincent Nguyen1,2, Anna Aryee1, Wing Lam Erica Fong1, Cyril Geismar1,2, Parth Patel1, Madhumita Shrotri1, Nicholas Patni4, Isobel Braithwaite1, Annalan M D Navaratnam1,2, Robert W Aldridge1 and Andrew Hayward2 on behalf of Virus Watch Collaborative**

** Anne M Johnson5, Linda Wijlaars6, Pia Hardelid6, Eleni Nastouli6,7, Moira Spyer7,7, Ben Killingley8,9, Ingemar Cox10, Vasileios Lampos10, Susan Michie11, Rachel A McKendry12, Tao Cheng13, Yunzhe Liu13, Jo Gibbs5, Richard Gilson5, Alison Rodger5,14

\section{Affiliations}

1. Centre for Public Health Data Science, Institute of Health Informatics, University College London, UK.

2. Institute of Epidemiology and Health Care, University College London, London, UK

3. Department of Infectious Disease Epidemiology, London School of Hygiene and Tropical Medicine, Keppel Street, London, UK.

4. University of Oxford Medical School, Medical Sciences Divisional Office University of Oxford, John Radcliffe Hospital, Oxford, UK

5. Institute for Global Health, University College London, London, UK.

6. Department of Population, Policy and Practice, UCL Great Ormond Street Institute of Child Health, London, UK.

7. Francis Crick Institute, London, UK.

8. Health Protection and Influenza Research Group, Division of Epidemiology and Public Health, University of Nottingham School of Medicine, Nottingham, United Kingdom.

9. University College London Hospital, London, United Kingdom.

10. Department of Computer Science, University College London, London, UK.

11. Centre for Behaviour Change, University College London, London, UK.

12. London Centre for Nanotechnology and Division of Medicine, London, UCL.

13. SpaceTimeLab, Department of Civil, Environmental and Geomatic Engineering, University College London, London, UK.

14. Royal Free London NHS Foundation Trust, London, UK. 
medRxiv preprint doi: https://doi.org/10.1101/2021.06.11.21258730; this version posted June 16, 2021. The copyright holder for this preprint

(which was not certified by peer review) is the author/funder, who has granted medRxiv a license to display the preprint in perpetuity.

It is made available under a CC-BY 4.0 International license.

\begin{abstract}
We aimed to assess the relative importance of different settings for SARS-CoV2 transmission in a large community cohort. We demonstrate the importance of home, work and education as venues for transmission. In children, education was most important and in older adults essential shopping was of high importance. Our findings support public health messaging about infection control at home, advice on working from home and restrictions in different venues.

\section{Background}

Risk factors for the transmission of SARS-CoV2 are understood to be driven by the complex interplay of a range of factors that can be broadly classified into four main areas[1] including viral load dynamics[2], contact patterns[3,4], environmental factors[5] and socioeconomic inequalities[6-8]. However, the relative contribution of different settings to overall transmission has proven difficult to quantify at a population level.[1] A lack of evidence about their relative contribution to transmission limits our ability to make evidence-based decisions about which settings should be the focus of control measures at different stages of the pandemic as different public health and policy actions are required. In this analysis, we aimed to assess the perceived relative importance of different settings for SARS-CoV2 transmission in a large community cohort (Virus Watch).
\end{abstract}

\title{
Perceived Setting of SARS-CoV-2 Acquisition
}

Virus Watch is a household community cohort study which began recruitment in June 2020 and has recruited circa 50,000 individuals across England and Wales with weekly online follow up and selfreporting of any positive SARS-CoV2 virological tests.[9] On the 17th of March 2021, participants were asked, "If you have had a positive COVID-19 swab test at any point in the pandemic, did you test positive after:...". Possible responses were "Contact with confirmed COVID-19 case(s)", "Contact with suspected COVID-19 case(s)", "No known contact with confirmed or suspected COVID-19 case(s)", or "I have not had a positive COVID-19 swab test during the pandemic". Participants who answered anything other than "I have not had a positive COVID-19 swab test during the past month" were then asked "Where do you think you may have caught COVID-19?". Participants were allowed to select more than one setting category and we classified these settings into the following groups: home, someone else's home, work, place of education, public transport, essential shop, healthcare setting, leisure (comprising 'bar, pub, or club', 'eating out in a restaurant, cafe, or canteen', 'gym/indoor sports facility', 'hairdresser, barber, nail salon, or similar location', and 'shop for nonessential items'), and other. Survey responses were linked to a previously reported date of infection, where available.

Using these data, we described the perceived setting of SARS-CoV-2 acquisition by contact status and stratified these descriptive analyses by age of the case and by time period of infection (Jan-May 2020, Jun-Aug 2020, Sep 2020-Dec 2020, Jan-March 2021). The survey was sent to 21,444 households comprising 45,654 study participants on 17/03/2021, and 18,096 (40\%) individual participants had completed the survey in full when data were extracted on 28/03/2021. Of these, 1142 participants had self-reported a positive SARS-CoV2 test previously during follow-up and responded to the main question of interest. $499(44 \%)$ reported known contact with a confirmed case, $120(10 \%)$ contact with a suspected case and $523(46 \%)$ reported no known contact. Amongst all cases, the perceived setting of acquisition was, in descending order of frequency, within the home $(n=317,33 \%)$, at work $(n=259,23 \%)$, in an essential shop $(n=201,18 \%)$, other venues $(n=129,11 \%)$, in a leisure venue $(n=112,10 \%)$, in a place of education $(n=96,8 \%)$, in healthcare settings $(n=90,8 \%)$, on public transport $(n=75,7 \%)$, and in someone else's home $(n=64,6 \%$; Table 1$)$. This varied considerably by whether or not the person was a contact of a known case or not (Figure 1).

For those with known contact with a confirmed case, the perceived venues for transmission in descending order of frequency were: home $(n=234,47 \%)$, work $(n=116,23 \%)$, education $(n=44,9 \%)$, someone else's home $(n=39,8 \%)$, healthcare setting $(n=35,7 \%)$, essential shop $(n=28,6 \%)$, other venues $(n=25,5 \%)$, and leisure venue $(n=17,3 \%)$. For those with no recognized contact, the perceived venues for acquisition were: an essential shop $(n=167,32 \%)$, work $(n=101,19 \%)$, other venues $(n=99,19 \%)$, home $(n=98,19 \%)$, a leisure venue $(n=86,16 \%)$, transport $(n=58,11 \%)$, healthcare $(n=48,9 \%)$, education $(n=42,8 \%)$, and someone else's home $(n=13,3 \%)$. 
medRxiv preprint doi: https://doi.org/10.1101/2021.06.11.21258730; this version posted June 16, 2021. The copyright holder for this preprint

(which was not certified by peer review) is the author/funder, who has granted medRxiv a license to display the preprint in perpetuity.

It is made available under a CC-BY 4.0 International license.

The most important perceived venue for transmission varied by age group: place of education was more important than home for children aged 0-17, home and workplace were of similar importance for working age adults, and home and essential shops were the most important settings for those aged over 65 years (Table 2). Young adults aged 18-34 were more likely than other age groups to perceive leisure venues and public transport as the venue of acquisition.

Home settings had a relatively stable level of perceived importance between Jan-May $2020(n=21$, 34\%) and Jan-March 2021 ( $n=106,30 \%$; Table 3). The proportions for someone else's home increased over time ( $n=0,0 \%$ Jan-May 2020 vs. $n=27,9 \%$ Jan-March 2021), as did place of education ( $n=0,0 \%$ vs. $n=12,4 \%)$. The proportion who perceived that they were infected in a healthcare setting decreased over time ( $n=18,26 \%$ vs. $n=25,8 \%)$. Caution should be used interpreting these time period changes because of small numbers for some groups, particularly in the Jun-Aug time period when levels of infection were low.

\section{Discussion}

Our findings illustrate the central perceived importance of home, work and place of education as venues for transmission, although the relative importance of different settings is likely to change over time and with variation in restrictions. In children, place of education is most important, and in older adults essential shopping is of high importance. Our estimates cover several periods of intense restrictions. As these restrictions loosen, the relative importance of out of household transmission is likely to increase.

Our study was reliant on community testing for case ascertainment so are most likely to represent infections acquired after the first UK lockdown following initiation of the Test, Trace and Isolate programme. Perceived venues of acquisition in those with known contact are likely biased toward venues such as home, work and education where contact tracing can readily lead to identification of known contact. Conversely those with no known contact may be more likely to conclude they acquired SARS-CoV2 infection in settings where they are in contact with strangers (such as in shops).

Considering these possible biases in reporting of the importance of these perceived settings by known or unknown contact status, our estimates provide useful upper and lower ranges for the likely relative importance of acquisition of SARS-CoV2 in England and Wales over our study period. In future waves of transmission, these findings can support public health messaging about infection control in the home, advice on working from home, restrictions in different venues, and advice to vulnerable elderly to reduce exposure to shops, for example through online shopping. 
medRxiv preprint doi: https://doi.org/10.1101/2021.06.11.21258730; this version posted June 16, 2021. The copyright holder for this preprint (which was not certified by peer review) is the author/funder, who has granted medRxiv a license to display the preprint in perpetuity.

It is made available under a CC-BY 4.0 International license .

Table 1. Perceived Setting of SARS-CoV2 Acquisition by Contact Status I

\begin{tabular}{|c|c|c|c|c|}
\hline & \multicolumn{4}{|c|}{ Contact with Confirmed or Suspected Case } \\
\hline & $\begin{array}{c}\text { Confirmed }^{1} \\
\text { N=499 }\end{array}$ & $\begin{array}{c}\text { Suspected } \\
\quad \mathrm{N}=120\end{array}$ & $\begin{array}{l}\text { None }{ }^{1} \\
\mathrm{~N}=523\end{array}$ & $\begin{array}{l}\text { Overall }^{1} \\
\mathrm{~N}=1142\end{array}$ \\
\hline Home & $234(46.9 \%)$ & $41(34.2 \%)$ & $98(18.7 \%)$ & $373(32.7 \%)$ \\
\hline $\begin{array}{l}\text { Someone else's } \\
\text { home }\end{array}$ & $39(7.8 \%)$ & $12(10.0 \%)$ & $13(2.5 \%)$ & $64(5.6 \%)$ \\
\hline Work & $116(23 \%)$ & $42(35.0 \%)$ & $101(19.3 \%)$ & $259(22.7 \%)$ \\
\hline Place of education & $44(8.8 \%)$ & $10(8.3 \%)$ & $42(8.0 \%)$ & $96(8.4 \%)$ \\
\hline Public transport & $10(2.0 \%)$ & $7(5.8 \%)$ & $58(11.1 \%)$ & $75(6.6 \%)$ \\
\hline Essential shop & $28(5.6 \%)$ & $6(5.0 \%)$ & $167(31.9 \%)$ & $201(17.6 \%)$ \\
\hline Healthcare setting & $35(7.0 \%)$ & $7(5.8 \%)$ & $48(9.2 \%)$ & $90(7.9 \%)$ \\
\hline Leisure & $17(3.4 \%)$ & $9(7.5 \%)$ & $86(16.4 \%)$ & $112(9.8 \%)$ \\
\hline Other & $25(5.0 \%)$ & $5(4.2 \%)$ & 99 (18.9\%) & $129(11.2 \%)$ \\
\hline
\end{tabular}

${ }^{1} \mathrm{n}(\%)$; Note: participants could select multiple locations so proportions are of category total not column total 
Table 2. Perceived Setting of SARS-CoV2 Acquisition by Age*

\begin{tabular}{|c|c|c|c|c|c|c|c|c|c|c|}
\hline & \multirow[b]{2}{*}{$\begin{array}{l}0 \text { to } 17 \\
\mathrm{~N}=120^{1}\end{array}$} & \multicolumn{4}{|c|}{ Overall } & \multicolumn{5}{|c|}{ Contact with Confirmed or Suspected Case } \\
\hline & & $\begin{array}{l}18 \text { to } 34 \\
\mathrm{~N}=191^{1}\end{array}$ & $\begin{array}{l}35 \text { to } 49 \\
\mathrm{~N}=262^{1}\end{array}$ & $\begin{array}{l}50 \text { to } 64, \\
\mathrm{~N}=361^{1}\end{array}$ & $\begin{array}{c}65+ \\
N=206^{1}\end{array}$ & $\begin{array}{l}0 \text { to } 17 \\
\mathrm{~N}=78^{1}\end{array}$ & $\begin{array}{l}18 \text { to } 34 \\
\mathrm{~N}=106^{1}\end{array}$ & $\begin{array}{l}35 \text { to } 49 \\
\mathrm{~N}=152^{1}\end{array}$ & $\begin{array}{l}50 \text { to } 64 \\
\mathrm{~N}=194^{1}\end{array}$ & $\begin{array}{c}65+ \\
N=87^{1}\end{array}$ \\
\hline Home & $\begin{array}{c}53 \\
(44.2 \%)\end{array}$ & $\begin{array}{c}64 \\
(33.5 \%)\end{array}$ & $\begin{array}{c}94 \\
(35.9 \%)\end{array}$ & $\begin{array}{c}100 \\
(27.7 \%)\end{array}$ & $\begin{array}{c}61 \\
(29.6 \%)\end{array}$ & $\begin{array}{c}41 \\
(52.6 \%)\end{array}$ & $\begin{array}{c}45 \\
(42.4 \%)\end{array}$ & $\begin{array}{c}71 \\
(46.7 \%)\end{array}$ & $\begin{array}{c}81 \\
(41.7 \%)\end{array}$ & $\begin{array}{c}36 \\
(41.4 \%)\end{array}$ \\
\hline Someone else's home & $2(1.7 \%)$ & $9(4.7 \%)$ & $9(3.4 \%)$ & $\begin{array}{c}21 \\
(5.8 \%)\end{array}$ & $\begin{array}{c}23 \\
(11.2 \%)\end{array}$ & $1(1.3 \%)$ & $6(5.7 \%)$ & $7(4.6 \%)$ & $18(9.3 \%)$ & $\begin{array}{c}19 \\
(21.8 \%)\end{array}$ \\
\hline Work & $2(1.7 \%)$ & $\begin{array}{c}61 \\
(31.9 \%)\end{array}$ & $\begin{array}{c}87 \\
(33.2 \%)\end{array}$ & $\begin{array}{c}98 \\
(27.1 \%)\end{array}$ & $\begin{array}{c}11 \\
(5.3 \%)\end{array}$ & $1(1.3 \%)$ & $\begin{array}{c}35 \\
(33.0 \%)\end{array}$ & $\begin{array}{c}56 \\
(36.8 \%)\end{array}$ & $\begin{array}{c}60 \\
(30.9 \%)\end{array}$ & $6(6.9 \%)$ \\
\hline Place of education & $\begin{array}{c}63 \\
(52.5 \%)\end{array}$ & $15(7.9 \%)$ & $8(3.1 \%)$ & $8(2.2 \%)$ & $1(0.5 \%)$ & $\begin{array}{c}37 \\
(47.4 \%)\end{array}$ & $10(9.4 \%)$ & $3(2.0 \%)$ & $3(1.5 \%)$ & $0(0.0 \%)$ \\
\hline Public transport & $4(3.3 \%)$ & $\begin{array}{c}22 \\
(11.5 \%)\end{array}$ & $15(5.7 \%)$ & $\begin{array}{c}22 \\
(6.1 \%)\end{array}$ & $\begin{array}{c}12 \\
(5.8 \%)\end{array}$ & $1(1.3 \%)$ & $3(2.8 \%)$ & $4(2.6 \%)$ & $6(3.1 \%)$ & $3(3.4 \%)$ \\
\hline Essential shop & $6(5.0 \%)$ & $\begin{array}{c}28 \\
(14.7 \%)\end{array}$ & $\begin{array}{c}51 \\
(19.5 \%)\end{array}$ & $\begin{array}{c}70 \\
(19.4 \%)\end{array}$ & $\begin{array}{c}46 \\
(22.3 \%)\end{array}$ & $1(1.3 \%)$ & $3(2.8 \%)$ & $7(4.6 \%)$ & $14(7.2 \%)$ & $\begin{array}{c}9 \\
(10.3 \%)\end{array}$ \\
\hline Healthcare setting & $0(0.0 \%)$ & $14(7.3 \%)$ & $20(7.6 \%)$ & $\begin{array}{c}32 \\
(8.9 \%)\end{array}$ & $\begin{array}{c}24 \\
(11.7 \%)\end{array}$ & $0(0.0 \%)$ & $10(9.4 \%)$ & 12 (7.9\%) & $12(6.2 \%)$ & $8(9.2 \%)$ \\
\hline Leisure & $5(4.2 \%)$ & $\begin{array}{c}28 \\
(14.7 \%)\end{array}$ & $19(7.3 \%)$ & $\begin{array}{c}36 \\
(10.0 \%)\end{array}$ & $\begin{array}{c}24 \\
(11.7 \%)\end{array}$ & $2(2.6 \%)$ & $7(6.6 \%)$ & $4(2.6 \%)$ & $8(4.1 \%)$ & $5(5.7 \%)$ \\
\hline Other & $4(3.3 \%)$ & 15 (7.9\%) & $19(7.3 \%)$ & $\begin{array}{c}43 \\
(11.9 \%)\end{array}$ & $\begin{array}{c}48 \\
(23.3 \%)\end{array}$ & $0(0.0 \%)$ & $3(2.8 \%)$ & 7 (4.6\%) & $12(6.2 \%)$ & 8 (9.2\%) \\
\hline
\end{tabular}

${ }^{1} \mathrm{n}(\%) ;$ * Two cases excluded due to missing age; Note: Participants could select multiple locations so proportions are calculated from group $n$ and may sum to $>100.0 \%$ 
Table 3. Perceived Setting of SARS-CoV2 Acquisition by Time Period

\begin{tabular}{|c|c|c|c|c|}
\hline Characteristic & Jan-May $2020, \mathrm{~N}=70^{1}$ & Jun-Aug 2020, $N=18^{1}$ & Sep 2020-Dec 2020, N = $377^{1}$ & Jan 2021-March 2021, $N=311^{1}$ \\
\hline Home & $21(30.0 \%)$ & $6(33.3 \%)$ & $113(30.0 \%)$ & $106(34.1 \%)$ \\
\hline Someone else's home & $0(0.0 \%)$ & $0(0.0 \%)$ & $22(5.8 \%)$ & $27(8.7 \%)$ \\
\hline Work & $22(31.4 \%)$ & $4(22.2 \%)$ & 97 (25.7\%) & $69(22.2 \%)$ \\
\hline Place of education & $0(0.0 \%)$ & $0(0.0 \%)$ & $54(14.3 \%)$ & 12 (3.9\%) \\
\hline Public transport & $5(7.1 \%)$ & $2(11.1 \%)$ & $30(8.0 \%)$ & $16(5.1 \%)$ \\
\hline Essential shop & 7 (10.0\%) & $4(22.2 \%)$ & $62(16.4 \%)$ & $71(22.8 \%)$ \\
\hline Healthcare setting & $18(25.7 \%)$ & $3(16.7 \%)$ & $17(4.5 \%)$ & $25(8.0 \%)$ \\
\hline Leisure & $4(5.7 \%)$ & $3(16.7 \%)$ & $53(14.1 \%)$ & $4(1.3 \%)$ \\
\hline Other & $7(10.0 \%)$ & $3(16.7 \%)$ & $34(9.0 \%)$ & $37(11.9 \%)$ \\
\hline
\end{tabular}

${ }^{1} \mathrm{n}(\%)$; Note: Participants could select multiple locations so proportions are calculated from group $n$ and may sum to $>100.0 \%$ 
Figure 1. Perceived Setting of SARS-CoV2 Acquisition by (a) Time Period, (b) Contact Status, (c) Age and (d) Age - Contacts of Confirmed or Suspected Cases.

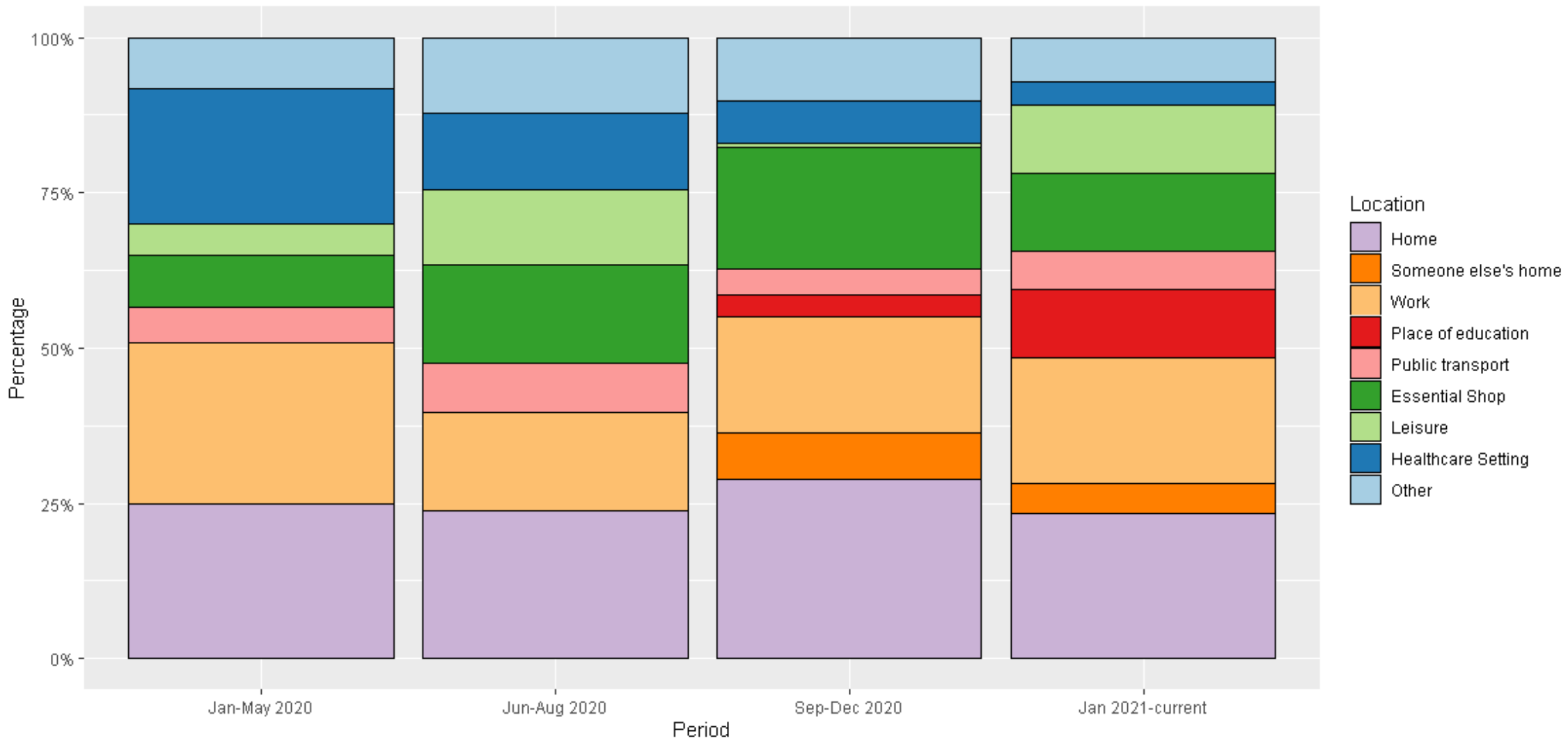




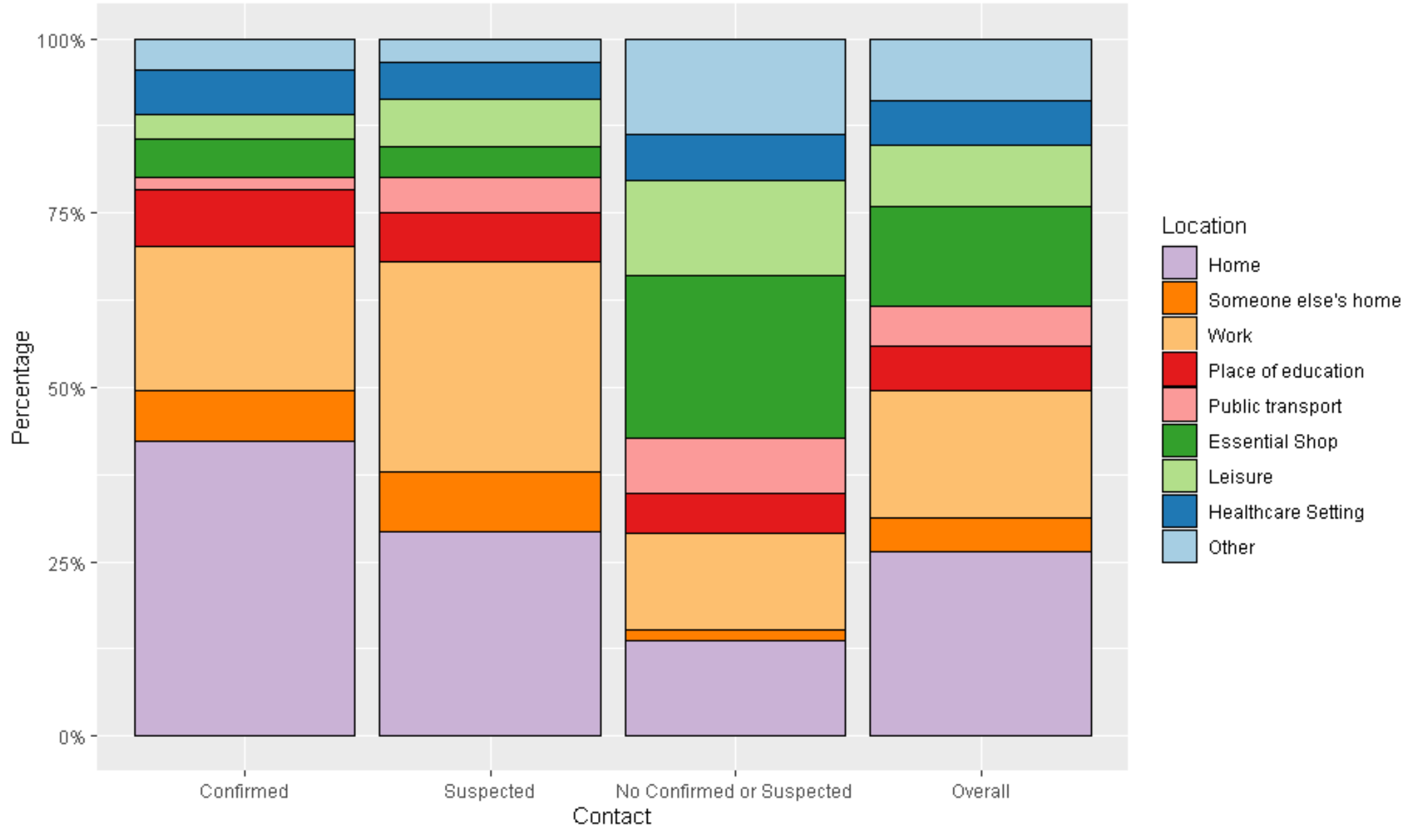




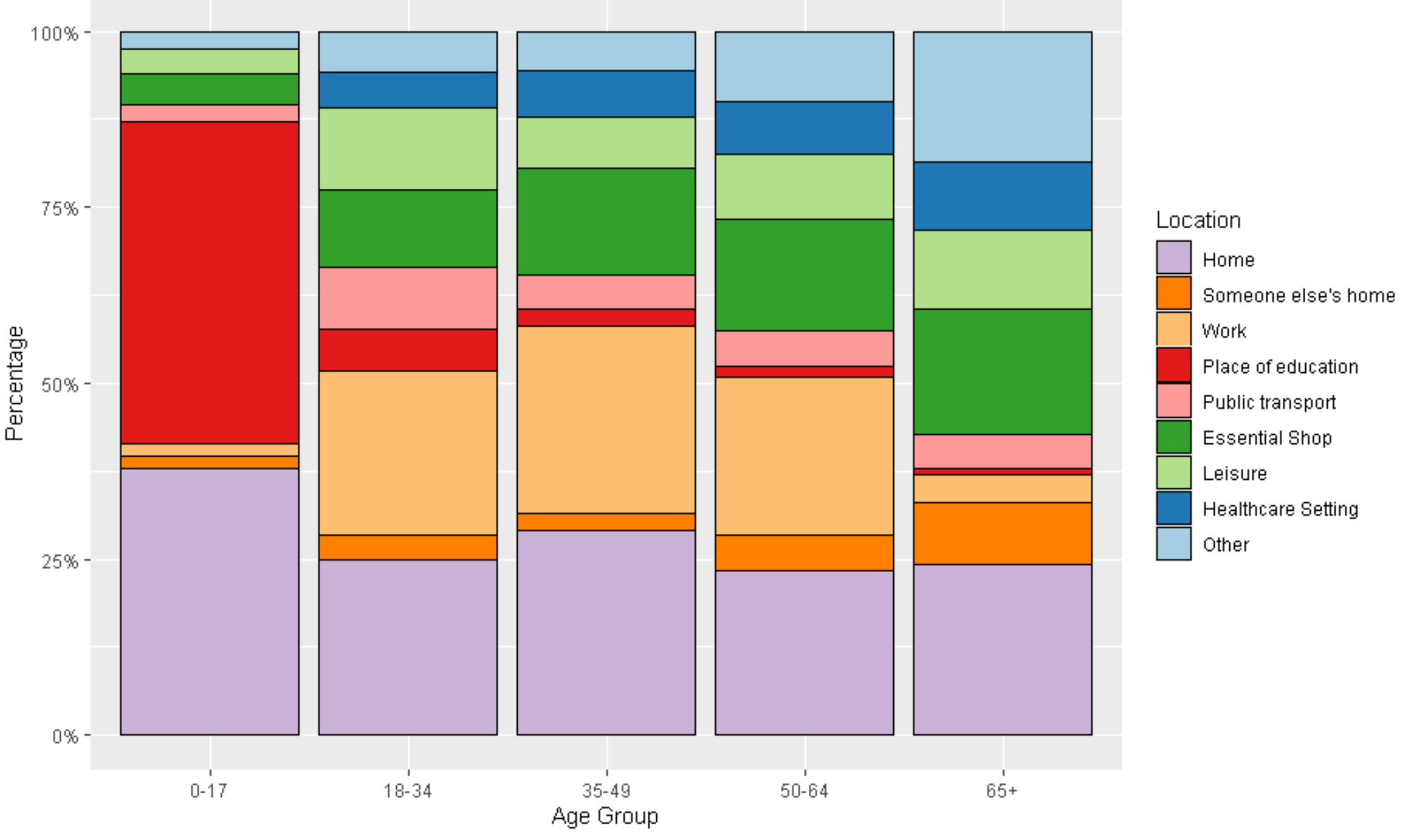




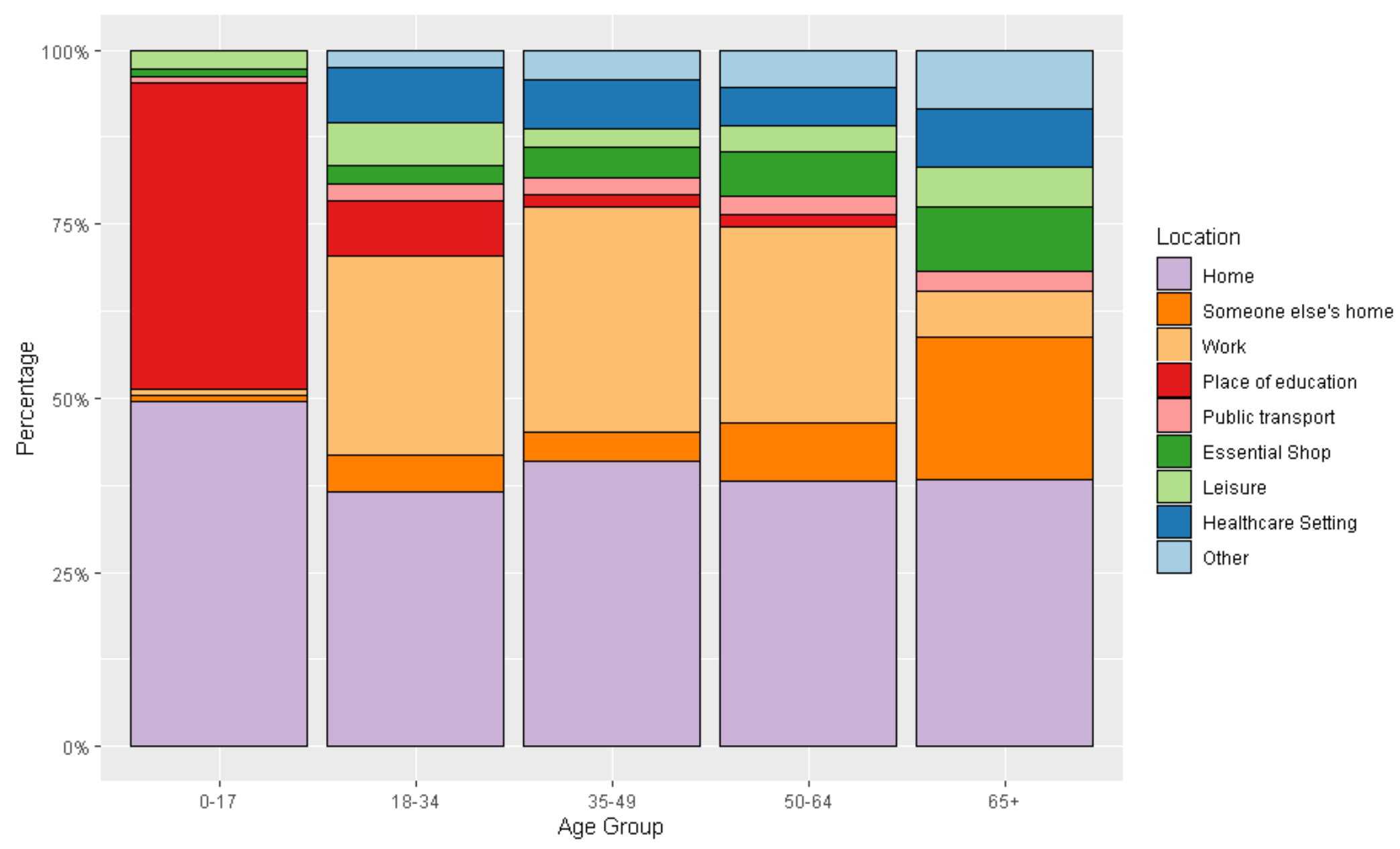

Note: Participants could select multiple locations so proportions are calculated from group $n$ and may sum to $>100.0 \%$ 
medRxiv preprint doi: https://doi.org/10.1101/2021.06.11.21258730; this version posted June 16, 2021. The copyright holder for this preprint (which was not certified by peer review) is the author/funder, who has granted medRxiv a license to display the preprint in perpetuity.

It is made available under a CC-BY 4.0 International license.

\section{References}

1. Scientific Advisory Group for Emergencies. PHE: Factors contributing to risk of SARS-CoV2 transmission in various settings, 26 November 2020. GOV.UK; 18 Dec 2020 [cited 9 Jun 2021]. Available: https://www.gov.uk/government/publications/phe-factors-contributing-to-risk-of-sarscov2-transmission-in-various-settings-26-november-2020

2. Cevik M, Tate M, Lloyd O, Maraolo AE, Schafers J, Ho A. SARS-CoV-2, SARS-CoV, and MERSCoV viral load dynamics, duration of viral shedding, and infectiousness: a systematic review and meta-analysis. Lancet Microbe. 2021;2: e13-e22.

3. Sun K, Wang W, Gao L, Wang Y, Luo K, Ren L, et al. Transmission heterogeneities, kinetics, and controllability of SARS-CoV-2. Science. 2021;371. doi:10.1126/science.abe2424

4. Government Office for Science. SARS-COV-2: Transmission Routes and Environments, 22 October 2020. GOV.UK; 6 Nov 2020 [cited 10 Jun 2021]. Available:

https://www.gov.uk/government/publications/sars-cov-2-transmission-routes-and-environments22-october-2020

5. Bulfone TC, Malekinejad M, Rutherford GW, Razani N. Outdoor Transmission of SARS-CoV-2 and Other Respiratory Viruses: A Systematic Review. J Infect Dis. 2021;223: 550-561.

6. Public Health England. COVID-19: review of disparities in risks and outcomes. GOV.UK; 2 Jun 2020 [cited 10 Jun 2021]. Available: https://www.gov.uk/government/publications/covid-19review-of-disparities-in-risks-and-outcomes

7. Aldridge RW, Pineo H, Fragaszy E, Eyre M, Kovar J, Nguyen V, et al. Household overcrowding and risk of SARS-CoV-2: analysis of the Virus Watch prospective community cohort study in England and Wales. medRxiv; 2021. doi:10.1101/2021.05.10.21256912

8. Beale S, Braithwaite I, Navaratnam AMD, Hardelid P, Rodger A, Aryee A, et al. Deprivation and exposure to public activities during the COVID-19 pandemic in England and Wales. medRxiv; 2021. doi:10.1101/2021.04.26.21255732

9. Hayward A, Fragaszy E, Kovar J, Nguyen V, Beale S, Byrne T, et al. Risk factors, symptom reporting, healthcare-seeking behaviour and adherence to public health guidance: protocol for Virus Watch, a prospective community cohort study. bioRxiv. medRxiv; 2020.

doi:10.1101/2020.12.15.20248254 